\title{
How do trees affect spatio-temporal heterogeneity of nutrient cycling in mediterranean annual grasslands?
}

\author{
Guillermo GEA-IzQUIERDo ${ }^{1 *}$, Barbara ALLEN-DÍAZ ${ }^{2}$, Alfonso SAN MIGUEL $^{3}$, Isabel CAÑELLAS ${ }^{1}$ \\ ${ }^{1}$ Departamento Sistemas y Recursos Forestales, CIFOR-INIA, Crta. La Coruña, km 7.5, 28040 Madrid, Spain \\ ${ }^{2}$ Ecosystem Sciences, UC Berkeley, CA 94720, USA \\ ${ }^{3}$ Departamento de Silvopascicultura, E.T.S.I Montes, UPM, Ciudad Universitaria s/n, 28040 Madrid, Spain
}

(Received 11 November 2008; revised version 26 January 2009; accepted 5 July 2009)

\author{
Keywords: \\ dehesa / \\ silvopastoral / \\ spatial heterogeneity / \\ facilitation / \\ competition
}

\begin{abstract}
- In this study we analyzed heterogeneity in nutrient cycling induced by trees in Mediterranean annual grasslands, comparing years of higher and lower than average precipitation and analyzing the effects of two different solar radiation scenarios.

- Organic matter and consequently upper soil $\mathrm{N}, \mathrm{K}, \mathrm{Ca}$ and $\mathrm{Mg}$ were significantly greater in those locations receiving the highest levels of solar radiation, and as expected from many other studies in the literature, there was an increase in all macronutrients (except $\mathrm{P}$ ) as well as $\mathrm{pH}$ below the canopy. - Contrary to what was expected, plant nutrient concentrations did not directly reflect those found in the soil, with the exception of $\mathrm{K}$. The studied grassland responded to increased nutrient availability by enhancing growth and changing botanical composition rather than by increasing plant nutrient concentrations. Hence, the total amount of accumulated nutrients in the ecosystem was larger below the tree than outside it, although this is mainly a consequence of plant growth enhancement. The levels of $\mathrm{Ca}, \mathrm{Mg}$, and $\mathrm{Na}$ in plants decreased during the driest year, and the $\mathrm{N}$ content was mostly determined by the composition of the grass.

- Temporal nutrient variability, particularly within-years, explained most of the variability in plant nutrient concentration, while spatial variability induced by trees was determined to be of secondary importance. These results are significant for ecosystem nutrient modelling.
\end{abstract}

Résumé - Comment les arbres affectent-ils l'hétérogénosité spatio-temporelle du cycle des nutriments dans une prairie méditerranénne annuelle?

- Dans cette étude, nous avons analysé l'hétérogénéité du cycle des nutriments induite par les arbres dans les prairies méditerranéennes annuelles, en comparant les années à précipitations supérieures et inférieures à la moyenne et en analysant les effets de deux scénarios de rayonnements solaires différents.

- La matière organique et par conséquent $\mathrm{N}, \mathrm{K}, \mathrm{Ca}$ et $\mathrm{Mg}$ des horizons supérieurs du sol étaient significativement plus élevés dans les stations recevant le plus de rayonnement solaire. Comme prévu à partir de nombreuses autres études dans la littérature, une augmentation de tous les macronutriments (sauf P) et aussi du pH a été observée sous la canopée des arbres.

- Contrairement à ce qui était prévu, les concentrations de nutriments dans les végétaux n'ont pas reflété directement celles trouvées dans le sol, à l'exception de K. Les prairies étudiées ont répondu à un accroissement de la disponibilité en éléments nutritifs par une augmentation de la croissance et un changement de la composition botanique plutôt que par une augmentation des concentrations de nutriments dans les plantes. Par conséquent, les quantités totales de nutriments accumulées dans l'écosystème étaient plus importantes sous les arbres qu'en plein découvert, bien que cela soit principalement une conséquence de l'amélioration de la croissance des plantes. Les niveaux de $\mathrm{Ca}, \mathrm{Mg}$, et $\mathrm{Na}$ dans les plantes ont diminué au cours de l'année la plus sèche et la teneur en nutriments azotés était largement déterminée par la composition de l'herbe.

- La variabilité temporelle intra-annuelle des éléments nutritifs expliquait la plus forte part de la variabilité de la concentration en nutriments des plantes annuelles, tandis que la variabilité spatiale induite par les arbres était d'importance secondaire. Ces résultats sont importants pour la modélisation des éléments nutritifs dans les écosystèmes.

\footnotetext{
*Corresponding author: guigeiz@gmail.com; guillermo.gea@wsl.ch
} 


\section{INTRODUCTION}

Growth of individual species can be limited by different nutrients and the effects of site fertility on individual plants are governed by the availability of the limiting nutrients (Barker and Pilbeam, 2007; Koerselman and Meuleman, 1996). The growth response which results from the addition of a limiting nutrient can be extrapolated to any other non-nutritional factor capable of limiting growth, such as moisture or light availability. Furthermore, different species within the same community are likely to respond differently to the same stimuli and the behaviour of different variables such as biomass growth or nutrient concentration may differ.

Facilitation and competition processes play a basic role in ecology and they can coexist in time and space within the same system. Consequently, the prediction and modelling of plantplant interactions is not straightforward (Brooker et al., 2008; Ludwig et al., 2001). In ecological systems such as savannas and open woodlands, a tree stratum coexists with either an herbaceous stratum or a shrub stratum or both. Hence understanding plant-plant interactions among strata is a crucial step in modelling and managing these ecosystems.

Trees modify the nutrient content of soils below their canopies through litterfall deposition and leaching (from plants, dry deposition and throughfall/stemflow), and indirectly through the activity of animals (e.g. De Schrijver et al., 2007; Escudero et al., 1985; Rodá et al., 1999). Nutrient response seems to be dependent on tree species, climate and soil type. The nutrient content of upper soil organic matter (OM) increases below the canopy along with total nitrogen $(\mathrm{N})$, calcium $(\mathrm{Ca})$, potassium $(\mathrm{K})$ and magnesium $(\mathrm{Mg})$, although the results of previous studies differ as regards the effect of trees on variables such as soil $\mathrm{pH}$ or phosphorus $(\mathrm{P})$ content (e.g. Eviner and Chapin III, 2003; Ludwig et al., 2001; Rhoades, 1997). Trees reduce solar radiation availability to understory vegetation as trees intercept light. Furthermore, roots compete for water and nutrients with understory vegetation (e.g. Ludwig et al., 2004) and precipitation is redistributed by canopies (Rodá et al., 1999). This leads to a series of interactions depending on the variable in question (i.e. biomass, nutrients, etc). These interactions affect biogeochemical cycles (Eviner and Chapin III, 2003) and therefore influence not only plant growth and distribution but also livestock and wildlife management, and even greenhouse gas (GHG) cycles, as in the case of $\mathrm{N}$ or $\mathrm{C}$. Explaining the variation in the levels of certain elements is not an easy task since the nutrient cycle may differ according to a number of factors such as plant community type (e.g. annuals, perennials), climate or soil bedrock (Ludwig et al., 2001; Rodá et al., 1999).

The most extended landscape in Western Iberia is an open woodland of perennial oaks (Quercus ilex L., Q. suber L.) with crops, pastures and shrublands intermixed, called "dehesa" ("montado" in Portugal). This system has been created by humans with a pastoral objective. Soils are generally sandy and of low fertility, most often derived from granites, quartzites, schists and slates (e.g. Joffre et al., 1988; Olea and San Miguel, 2006). Low soil fertility is one of the explanations of the silvopastoral (and not purely agricultural) use of this system
(Olea et al., 1990-1991; Olea and San Miguel, 2006). It is important, therefore, to identify the mechanisms which may increase fertility, such as the redistribution of nutrients by trees or as a result of the topography (e.g. Gallardo, 2003; Puerto and Rico, 1992). In this system, the understory is mainly composed of two ecological types of herbaceous communities, each displaying a different phenology and composition; (i) annual-perennial grasslands, either thriving on the most fertile and humid soils (foothills) or on soils where OM and water retention capacity have been increased through livestock (sheep) management; and (ii) annual grasslands. A large number of studies concerned with the interactions between trees and understory vegetation (either from an ecological or pastoral perspective), have been conducted in more productive annual-perennial communities whereas fewer studies have been published in relation to less productive annual grasslands (e.g. Montalvo et al., 1980; Puerto and Rico, 1996). Despite sharing the same climate, the nutrient cycles in these two different ecological systems are likely to vary, as will the plantplant interactions.

In this study, we examine the influence of the tree stratum upon grassland nutrient cycles in the low fertility annual grass/tree ecosystem in 'dehesas'. We hypothesized that changes in soil nutrient availability and soil moisture would lead to differences in plant nutrient concentrations (Barker and Pilbeam, 2007). Our objectives were: (i) to assess whether the asymmetric interception (differences between orientations) of light by trees results in soil property differences; (ii) to discuss the variation induced in annual plant nutrient content by tree derived spatial differences in fertility; (iii) to compare the variation in plant nutrient contents in years of contrasting precipitation. Variables of both ecological and pastoral interest are discussed.

\section{MATERIAL AND METHODS}

\subsection{Study area and sampling design}

Ten holm oak trees were used as replicates in an open woodland in West Central Spain $\left(39^{\circ} \mathrm{N} 5^{\circ} \mathrm{W}\right)$. The mean tree density of the stand was around 10 trees/ha, and the mean diameter, height and crown radius of the trees were $63.5(26.0) \mathrm{cm}, 8.8(1.6) \mathrm{m}$ and 4.9 (1.8) $\mathrm{m}$ respectively (standard deviation in brackets). The climate was continental Mediterranean, with a mean precipitation of $573 \mathrm{~mm}$. The characteristic Mediterranean long summer drought period usually lasts over 3 months. During the study period (20042006) annual precipitation was 782.3 (214.1), 343.9 (96.5) and 583.0 (205.3) $\mathrm{mm}$ respectively (March-May in parenthesis). The understory vegetation was annual grassland both below and beyond the canopy (Gea-Izquierdo, 2009).

The interaction between the tree and the understory vegetation was studied by analyzing the response of soil and plant nutrients as dependent variables to two independent factors, namely: (i) distance from the tree (DT), in order to study the spatial extent of its influence (indirect shade, nutrients, competition); and (ii) orientation (OR), to study the differential effect of solar radiation and the asymmetry of 
the crown effect. Grazing was excluded either by fencing trees or using cages. In 2004, 16 sampling points were placed proportionally to the crown radius $(R)$ of each tree (hence, from 0.25 times $R$ to 2.0 times $R$, hereafter $0.25 R, 0.5 R, \ldots$, and $2.0 R$ ) in the most and least shaded orientations: 8 sampling points to the North-East (NE), lowest exposition to sunlight, and 8 in the South-West (SW), highest exposition. A total of 160 sampling points were used to study the spatial variation in plant nutrients. In the following years, 20052006, two sampling points per orientation were established in order to study the temporal variation in plant nutrients (below) and (beyond) the canopy. These were situated at $0.5-0.75 R$ "below" and $1.75-2.0 R$, "beyond" for each orientation, hence, four per tree (totalling 40 samples/sampling date).

\subsection{Data collection and chemical analyses}

The herbaceous material was collected from $20 \times 50 \mathrm{~cm}$ frames in 2004 and $50 \times 50 \mathrm{~cm}$ squares in the following years. The material collected was dried for $48 \mathrm{~h}$ at $60{ }^{\circ} \mathrm{C}$. The grass is generally dry between mid June and October, and reaches maturity around late April-May. Plant material was collected in mid April and at the end of May (end of the vegetative period, to estimate annual yield). In 2006, material was also collected in July from the NE side of the trees in order to determine the lowest nutrient content of the dry plants and evaluate their potential for livestock and wildlife grazing in summer.

In May 2006, soil data were collected from the top $20 \mathrm{~cm}$ of soil at 72 sampling points around 6 trees. The samples were collected at 6 distances proportional to the crown radius (from $0.375 R$ to $2.5 R$ ) in the same two orientations (NE, SW). Soil data for estimating bulk density were collected in October 2007. The soil samples were airdried, then sieved $(<2 \mathrm{~mm})$ and analyzed for organic matter (OM), total nitrogen $(\mathrm{N})$; available phosphorus $(\mathrm{P})$ using the Bray procedure; potassium $(\mathrm{K})$, calcium $(\mathrm{Ca})$, magnesium $(\mathrm{Mg})$, cation exchange capacity (CEC), $\mathrm{pH}, \mathrm{C}: \mathrm{N}$ ratio and particle size (following USDA Standards; Brady and Weil, 2002). Plant nutrient content was analyzed for $\mathrm{N}, \mathrm{P}, \mathrm{K}, \mathrm{Ca}, \mathrm{Mg}$, copper $(\mathrm{Cu})$ each year and iron $(\mathrm{Fe})$, sodium $(\mathrm{Na})$, neutral detergent fibre (NDF), acid detergent fibre (ADF) and lignin only in 2005-06.

\subsection{Statistical Analysis}

The data collected presented both spatial and temporal correlation so, to accurately test for differences between sample points, and since the dependent data approached the normal distribution, we used linear mixed models (Verbeke and Mohlenbergs, 2000). Data from 2004 were analyzed considering "DT", "OR" and the interaction between the two as fixed effects. The residual variance-covariance matrix was modelled using a first-order autoregressive structure (AR(1)) and submatrices corresponding to within-tree observations. When data from the period 2004-06 were analyzed (distance coded simply as "below" or "beyond"), month and year (and their interactions) were also considered as fixed effects, and the linear model included a random intercept effect to account for the temporal correlation. In this case the residual covariance matrix $(R)$ was either not specified (hence it was denoted $I \cdot \sigma^{2}$ ) or had a Toeplitz $(r)$ structure when the nested log-likelihood ratio test was significant (Verbeke and Mohlenberghs, 2000). To test for differences within fixed effects we used contrasts compared to an F distribution (Verbeke and Mohlenberghs, 2000).

\section{RESULTS}

\subsection{Tree effects on the spatial variation of upper soil nutrients in annual grasslands}

The studied upper soil layer had very low nutrient content (Fig. 1; Appendix ${ }^{1}$ ). Soil nutrients were clearly dependent on the distance from the tree, as expected. No DT*OR interaction was significant (e.g. for OM, $F_{5,46}=0.52, p=0.7609$ ). OM decreased with distance from the tree as far as the crown edge (Fig. 1, $F_{1,62}=18.57, p<0.0001$ ), and was similar in positions beyond the canopy $\left(F_{1,62}=1.44, p=0.2351\right)$. The other soil nutrients directly related to OM followed a similar pattern, with the exception of soil-P, which did not show any significant difference with distance from the tree $\left(F_{5,57}=1.37\right.$, $p=0.2478)$. Soil-P exhibited high variability in the studied soil (Fig. 1; Appendix $\left.{ }^{1}\right)$. Soil-N $\left(F_{1,62}=13.51, p=0.0005\right)$, soil-K $\left(F_{1,61}=28.05, p<0.0001\right)$, soil-Ca $\left(F_{1,62}=60.43\right.$, $p<0.0001)$, soil-Mg $\left(F_{1,60}=51.09, p<0.0001\right)$, and CEC $\left(F_{1,62}=7.48, p=0.0081\right)$ decreased almost monotonically with distance from the tree bole (Fig. 1). Sampling points located outside the vertical crown projection, hence, the area expected to be least influenced by litterfall and root litter, did not show significant differences. $\mathrm{pH}$ also clearly decreased with distance from the tree $\left(F_{1,62}=42.46, p<0.0001\right)$ and was also highest at the location closest to the tree base. Bulk density showed the opposite behaviour presenting maximum values at the locations furthest from the tree base $\left(F_{1,46}=29.20\right.$, $p<0.0001)$. Clay content was very low and did not change significantly with distance from the tree base $\left(F_{5,56}=0.94\right.$, $p=0.4597)$.

Differences in solar radiation resulted in significant differences in the availability of most soil nutrients; generally, nutrients increased with higher levels of solar radiation. There was more OM to the SW than to the NE $\left(F_{1,24}=6.79, p=0.0155\right)$ and this tendency was also identified for most of the soil nutrients directly related to OM, such as $\mathrm{N}\left(F_{1,28}=5.82, p=\right.$ $0.0226), \mathrm{K}\left(F_{1,22}=10.03, p=0.0073\right)$, and $\mathrm{Mg}\left(F_{1,22}=9.47\right.$, $p=0.0056)$; with $\mathrm{Ca}\left(F_{1,22}=3.13, p=0.0904\right)$ and bulk density $\left(F_{1,28}=3.05, p=0.0918\right)$ being significant at $\alpha=0.10$. However, soil-P $\left(F_{1,31}=0.01, p=0.9070\right)$, pH $\left(F_{1,26}=0.09\right.$, $p=0.7686)$, and CEC $\left(F_{1,27}=1.64, p=0.2108\right) \mathrm{did}$ not present significant differences between orientations. Finally, differences in the level of solar radiation received at each orientation appeared to result in slight variations in soil texture. A greater proportion of clay was present at the SW orientation $\left(F_{1,27}=5.11, p=0.0320\right)$, whereas the amount of sand only varied between orientations beyond the canopy $\left(F_{1,25}=5.20\right.$, $p=0.0312$ ), with NE locations having more sand, complementary to silt (not shown). Finally, the above mentioned differences in OR or DT were not accompanied by significant differences in mineralization conditions as estimated by the $\mathrm{C}: \mathrm{N}$ ratio $\left(\mathrm{OR}: F_{1,29}=0.06, p=0.8148\right.$; DT: $F_{5,53}=1.20$, $p=0.3237)$.

\footnotetext{
${ }^{1}$ Supplementary material available online only at www.afs-journal. org
} 

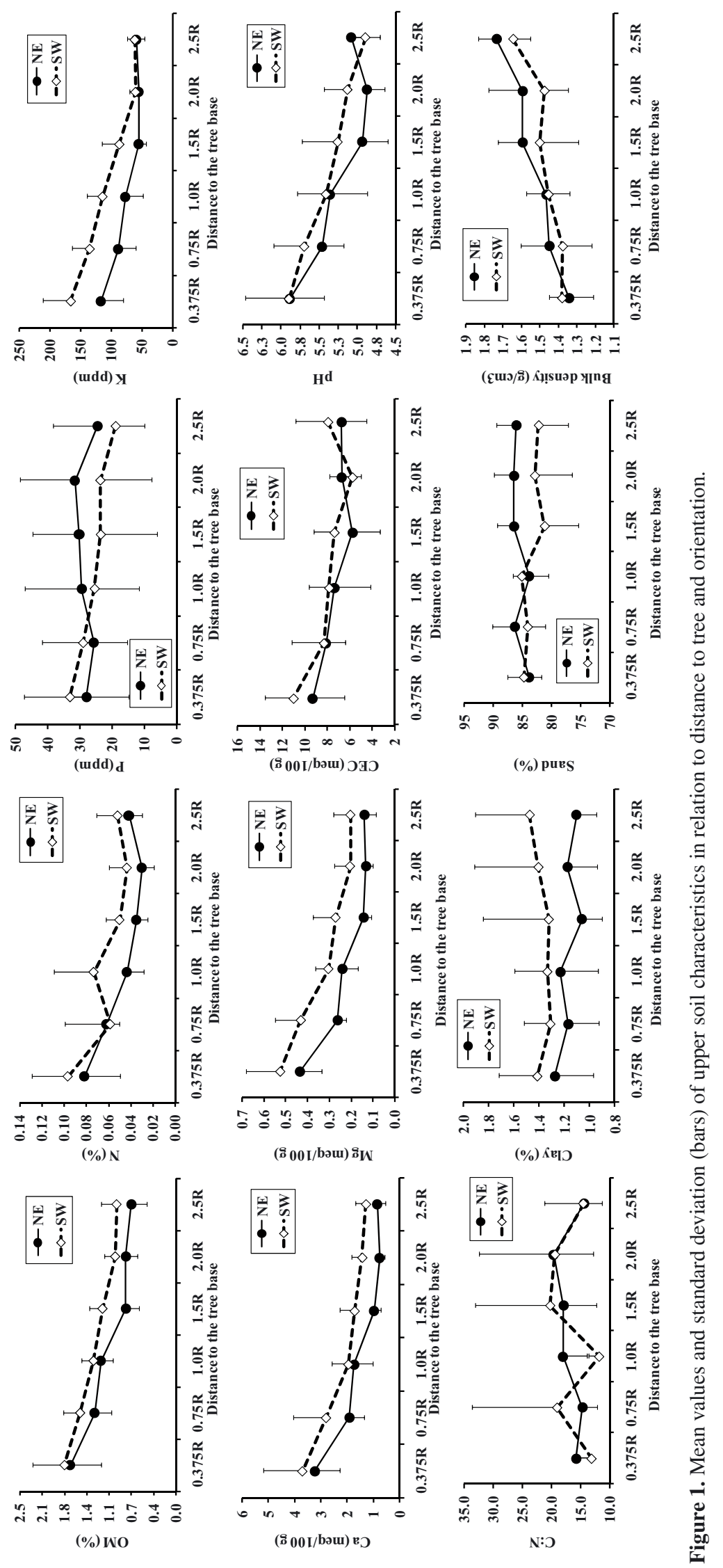

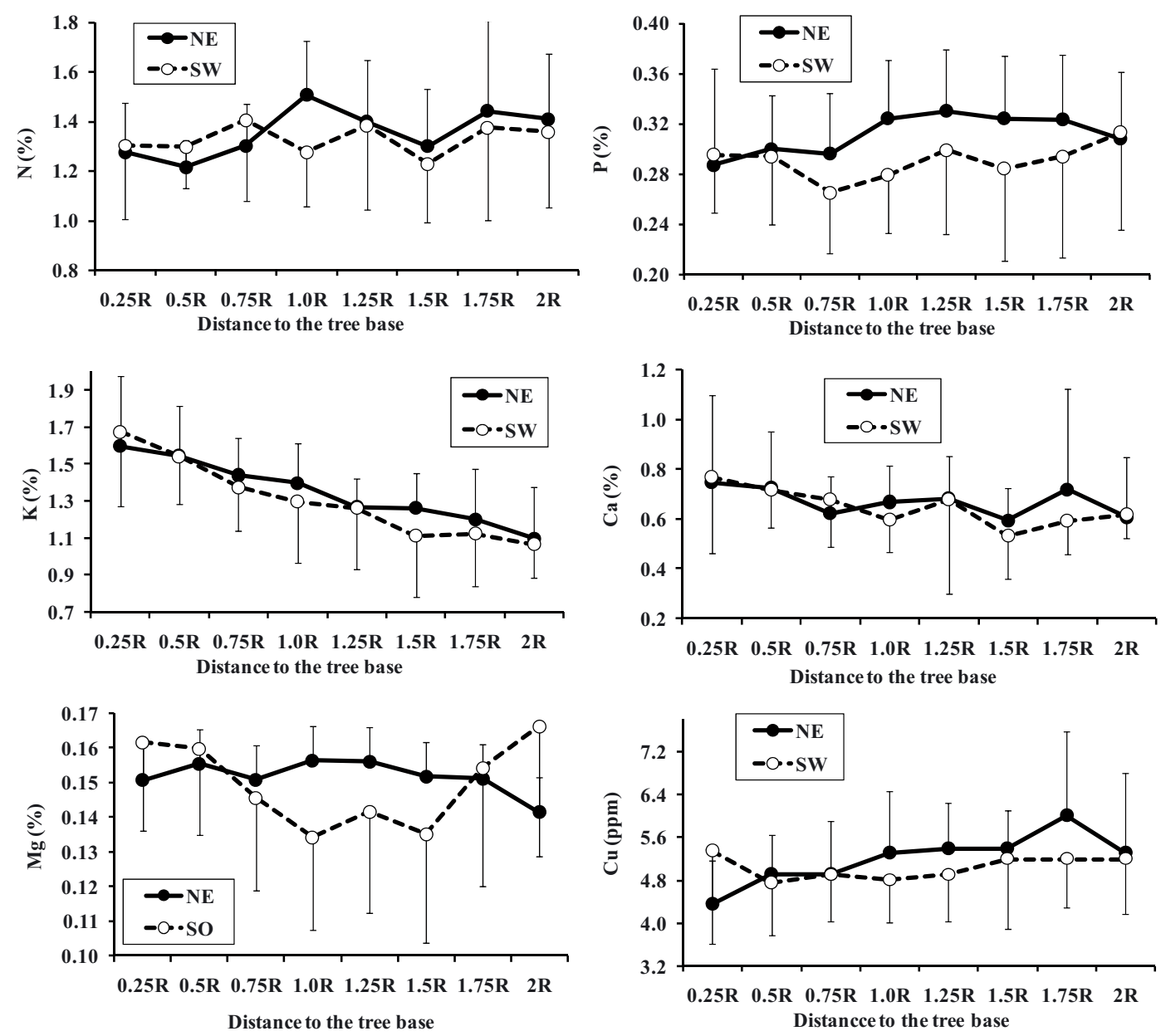

Figure 2. Spatial variation in plant nutrient content in year 2004: macronutrients and copper. Dots correspond to mean values whereas bars are standard deviations.

\subsection{Tree effects on the spatio-temporal variation of nutrients in annual grasslands}

The levels of nutrients in plants sampled in May 2004 (when more intensive sampling was carried out to study the spatial variation around trees) did not reflect the higher levels of most soil nutrients found in SW locations or closer to the tree base (Fig. 2). OR*DT interaction was not significant for any plant nutrient in 2004 (e.g. $F_{7,113}=1.23, p=0.2906$ for $\mathrm{N}$ ). Nitrogen in plants did not follow the same patterns found in soil-N: there was a slight increase in $\mathrm{N}$ with distance significant only with $\alpha=0.10\left(F_{7,119}=1.80, p=0.0926\right)$ and the effect of orientation was non-significant $\left(F_{1,46}=0.14\right.$, $p=0.7081)$. In fact, the $\mathrm{N}$ content of the grass appeared to be associated mainly with legume content (Pearson $\rho=0.872$; $p<0.0001 ; 2004$ legume data from Gea-Izquierdo, 2009). The only nutrient which clearly decreased in understory plants from the tree bole in understory plants was $\mathrm{K}\left(F_{1,100}=34.17\right.$, $p<0.0001)$. This decrease was similar for both orientations $\left(F_{1,42}=0.07, p=0.7884\right)$ and evident both below and beyond the canopy. Plant-Ca content was significantly higher for the two positions closest to the tree $\left(F_{1,106}=5.21\right.$, $p=0.0244)$, with no difference between orientations. Variations in plant-Mg with distance from the tree $\left(F_{7,130}=0.96\right.$, $p=0.4601)$ or orientation $\left(F_{1,44}=1.25, p=0.2692\right)$, were not significant.

However, differences in some of these relationships were identified when they were analyzed in different years (period 2004-06; Tab. I). As expected, there was a strong decrease in all plant nutrients as the season progressed (hereafter referred to as plant age or phenology) regardless of location with respect to the canopy (Fig. 3; Tab. I). For this reason, the small differences between orientations and years were difficult to analyze, since such variations may simply reflect differences in phenology at locations receiving different solar radiation (indirect effect of canopy light interception) rather than a response to increased soil nutrients. The significant interactions found between $\mathrm{N}$ and the other fixed effects (Tab. I) suggest that the effect of orientation changed according to the year and the effect of distance changed with plant age. It would appear that in the early vegetative period (April) the pasture below the canopy contained more $\mathrm{N}\left(F_{1,40}=21.75, p<0.0001\right)$ whereas in May and July there was no significant difference $\left(F_{1,76}=1.08, p=0.3019\right)$. Orientation was only significant 
Table I. Results from linear mixed model with plant macronutrient concentration and $\mathrm{Cu}$ as dependent variables for the period $2004-2006$. $\mathrm{DT}=$ distance to tree base; OR = orientation. $\sigma_{i}^{2}(\mathrm{~b})=$ variance estimate for intercept random effect. Toeplitz $=$ value for the log-likelihood ratio test $\left(\chi^{2}\right)$ testing the model with Toeplitz residual variance against the same model but with variance components residual variance $\left(I \cdot \sigma^{2}\right)$. July is not included in the analyses to balance the data.

\begin{tabular}{|c|c|c|c|c|c|c|c|c|c|c|}
\hline \multirow{2}{*}{ Parameter } & \multicolumn{2}{|c|}{$\mathrm{N}$} & \multicolumn{2}{|c|}{$\mathrm{P}$} & \multicolumn{2}{|c|}{$\mathrm{K}$} & \multicolumn{2}{|c|}{$\mathrm{Ca}$} & \multicolumn{2}{|c|}{$\mathrm{Mg}$} \\
\hline & $F(\mathrm{~d} f)$ & $p$-value & $F(\mathrm{~d} f)$ & $p$-value & $F(\mathrm{~d} f)$ & $p$-value & $F(\mathrm{~d} f)$ & $p$-value & $F(\mathrm{~d} f)$ & $p$-value \\
\hline DT & $\begin{array}{c}3.95 \\
(1,40)\end{array}$ & $0.0538^{*}$ & $\begin{array}{c}1.40 \\
(1.08)\end{array}$ & 0.3042 & $\begin{array}{l}122.28 \\
(1,62)\end{array}$ & $<0.0001^{* *}$ & $\begin{array}{c}26.92 \\
(1,77)\end{array}$ & $<0.0001^{* *}$ & $\begin{array}{c}3.96 \\
(1,22)\end{array}$ & $0.0595^{*}$ \\
\hline OR & $\begin{array}{c}1.32 \\
(1,37)\end{array}$ & 0.2589 & $\begin{array}{c}0.91 \\
(1,40)\end{array}$ & 0.3470 & $\begin{array}{c}0.00 \\
(1,65)\end{array}$ & 0.9603 & $\begin{array}{c}0.04 \\
(1,44)\end{array}$ & 0.8373 & $\begin{array}{c}0.50 \\
(1,35)\end{array}$ & 0.4829 \\
\hline Year & $\begin{array}{c}2.29 \\
(2,76)\end{array}$ & $0.0801^{*}$ & $\begin{array}{c}6.77 \\
(2,96)\end{array}$ & $0.0018^{* *}$ & $\begin{array}{c}3.21 \\
(2,28)\end{array}$ & $0.0553^{*}$ & $\begin{array}{c}19.22 \\
(2,27)\end{array}$ & $<0.0001^{* *}$ & $\begin{array}{c}28.36 \\
(2,30)\end{array}$ & $<0.0001^{* *}$ \\
\hline Month & $\begin{array}{c}48.28 \\
(1,15)\end{array}$ & $<0.0001^{* *}$ & $\begin{array}{c}66.65 \\
(1,95)\end{array}$ & $<0.0001^{* *}$ & $\begin{array}{l}132.20 \\
(1,11)\end{array}$ & $<0.0001^{* *}$ & $\begin{array}{l}60.27 \\
(1,9)\end{array}$ & $<0.0001^{* *}$ & $\begin{array}{l}108.13 \\
(1,14)\end{array}$ & $<0.0001^{* *}$ \\
\hline $\mathrm{DT} * \mathrm{OR}$ & $\begin{array}{c}0.90 \\
(1,32)\end{array}$ & 0.3509 & $\begin{array}{c}0.40 \\
(1,47)\end{array}$ & 0.4979 & $\begin{array}{c}0.01 \\
(1,67)\end{array}$ & 0.9183 & $\begin{array}{c}0.10 \\
(1,68)\end{array}$ & 0.7504 & $\begin{array}{c}0.47 \\
(1,31)\end{array}$ & 0.4989 \\
\hline DT*Year & $\begin{array}{c}0.08 \\
(2,54)\end{array}$ & 0.9270 & $\begin{array}{c}4.27 \\
(2,96)\end{array}$ & $0.0167^{* *}$ & $\begin{array}{c}4.17 \\
(2,69)\end{array}$ & $0.0196 *$ & $\begin{array}{c}5.22 \\
(2,63)\end{array}$ & $0.0080^{* *}$ & $\begin{array}{c}0.80 \\
(2,79)\end{array}$ & 0.4544 \\
\hline DT*Month & $\begin{array}{c}35.82 \\
(1,13)\end{array}$ & $<0.0001^{* *}$ & $\begin{array}{c}16.19 \\
(1,95)\end{array}$ & $0.0001^{* *}$ & $\begin{array}{c}17.64 \\
(1,30)\end{array}$ & $0.0002^{* *}$ & $\begin{array}{c}6.68 \\
(1.15)\end{array}$ & $0.0204^{* *}$ & $\begin{array}{c}3.03 \\
(1,22)\end{array}$ & $0.0962^{*}$ \\
\hline OR*Year & $\begin{array}{c}4.94 \\
(2,44)\end{array}$ & $0.0116^{* *}$ & $\begin{array}{c}3.89 \\
(2,96)\end{array}$ & $0.0238^{* *}$ & $\begin{array}{c}5.56 \\
(2,70)\end{array}$ & $0.0057^{* *}$ & $\begin{array}{c}1.79 \\
(2,45)\end{array}$ & 0.1794 & $\begin{array}{c}2.29 \\
(2,56)\end{array}$ & 0.1106 \\
\hline OR*Month & $\begin{array}{c}0.77 \\
(1,16)\end{array}$ & 0.3938 & $\begin{array}{c}10.89 \\
(1,95)\end{array}$ & $0.0014^{* *}$ & $\begin{array}{c}2.49 \\
(1,28)\end{array}$ & 0.1261 & $\begin{array}{c}3.39 \\
(1,37)\end{array}$ & $0.0738^{*}$ & $\begin{array}{c}3.72 \\
(1,33)\end{array}$ & $0.0623^{*}$ \\
\hline $\begin{array}{c}\text { DT*OR } \\
* \text { Year }\end{array}$ & $\begin{array}{c}1.06 \\
(2,47)\end{array}$ & 0.3536 & $\begin{array}{c}0.54 \\
(2,96)\end{array}$ & 0.5836 & $\begin{array}{c}0.60 \\
(2,61)\end{array}$ & 0.5519 & $\begin{array}{c}0.63 \\
(2,53)\end{array}$ & 0.5359 & $\begin{array}{c}0.34 \\
(2,48)\end{array}$ & 0.7125 \\
\hline $\begin{array}{l}\text { DT*OR } \\
* \text { Month }\end{array}$ & $\begin{array}{c}0.08 \\
(1,30)\end{array}$ & 0.7851 & $\begin{array}{c}0.01 \\
(1,95)\end{array}$ & 0.9130 & $\begin{array}{c}0.41 \\
(1,40)\end{array}$ & 0.5281 & $\begin{array}{c}0.06 \\
(1,32)\end{array}$ & 0.8099 & $\begin{array}{c}0.62 \\
(1,38)\end{array}$ & 0.4356 \\
\hline & $\begin{array}{c}\text { test } \\
\text { value }\end{array}$ & $p$-value & $\begin{array}{c}\text { test } \\
\text { value }\end{array}$ & $p$-value & $\begin{array}{c}\text { test } \\
\text { value }\end{array}$ & $p$-value & $\begin{array}{c}\text { test } \\
\text { value }\end{array}$ & $p$-value & $\begin{array}{c}\text { test } \\
\text { value }\end{array}$ & $p$-value \\
\hline$\sigma_{i}^{2}(\mathrm{~b})$ & 2.37 & $0.0090^{* *}$ & 2.56 & $0.0052^{* *}$ & 0.69 & 0.2442 & 0.51 & 0.3064 & 1.32 & $0.0933^{*}$ \\
\hline Toeplitz & 13.90 & $0.05298^{*}$ & 10.40 & 0.1670 & 20.20 & $0.0051^{* *}$ & 28.20 & $0.0002^{* *}$ & 24.80 & $0.0008^{* *}$ \\
\hline
\end{tabular}

* and $^{* *}$ meaning significance test at $\alpha=0.1$ and $\alpha=0.05$ respectively.

in $2006\left(F_{1,31}=14.45, p=0.0006\right)$, when the $\mathrm{SW}$ orientation returned higher levels of $\mathrm{N}$ than the $\mathrm{NE}$, coinciding with higher legume percentage also to the SW (Fig. 4; Gea-Izquierdo, 2009).

Plant-P did not show any clear trend with distance or orientation (Tab. I, Fig. 3). There was, however, a clear decrease with phenology in plant-K levels (Tab. I; Fig. 3). The significant interactions between plant-K and the other effects (Tab. I) are reflected by the greater differences detected in the samples taken in April, although the difference was still significant in July $\left(F_{1,68}=11.16, p=0.0014\right)$ when grass is dry. Ca was more abundant in plants below canopy (Tab. I, Fig. 3) but this was not significant in July $\left(F_{1,39}=0.64, p=0.4303\right)$. Plant-Ca levels decreased with each phenological stage (Fig. 3, Tab. I) and in 2005, the driest year, plant-Ca levels were significantly lower $\left(F_{1,34}=32.78, p<0.0001\right)$. In the case of plant-Mg, the most important factors were again differences in phenology (decreasing $\mathrm{Mg}$ with time; $F_{1,34}=32.78$, $p<0.0001)$ and, as with $\mathrm{Ca}$, the $\mathrm{Mg}$ levels were lowest in the driest year $\left(F_{1,59}=4.34, p=0.0417\right)$.

\subsection{Tree effect on grass variables of pastoral interest}

An increase in plant $\mathrm{Cu}$ with distance from the tree was only found in April and May of $2006\left(F_{1,141}=13.44, p=0.0003\right)$ since most of the variability was related to the month in which the samples were taken $\left(F_{1,98}=37.37, p<0.0001\right)$, hence plant age. In 2004 it was found that crude fibre significantly decreased with distance from the tree $\left(F_{7,89}=4.82, p<\right.$ $0.0001)$ only in the NE orientation $\left(F_{1,29}=4.45, p=0.0452\right)$. The decline in pasture quality as the growing season progressed (as previously described for $\mathrm{N}, \mathrm{P}, \mathrm{K}, \mathrm{Ca}, \mathrm{Mg}$ and $\mathrm{Cu}$ ) resulted in lower levels of $\mathrm{Fe}$ and $\mathrm{Na}$, and higher levels of NDF and ADF into the summer (Figs. 3, 5). The levels of Fe and $\mathrm{Na}$ reflect temporal rather than spatial variation (Fig. 5). Orientation was not significant in the case of NDF, and distance was only significant in May $\left(F_{1,86}=7.45, p=0.0077\right)$. Plants growing below the canopy only presented lower levels of ADF in April $\left(F_{1,54}=4.09, p=0.0482\right)$. Lignin fluctuated from April to July (Fig. 5), most of the variance being explained by the year $\left(F_{1,30}=51.25, p<0.0001\right)$ whereas 

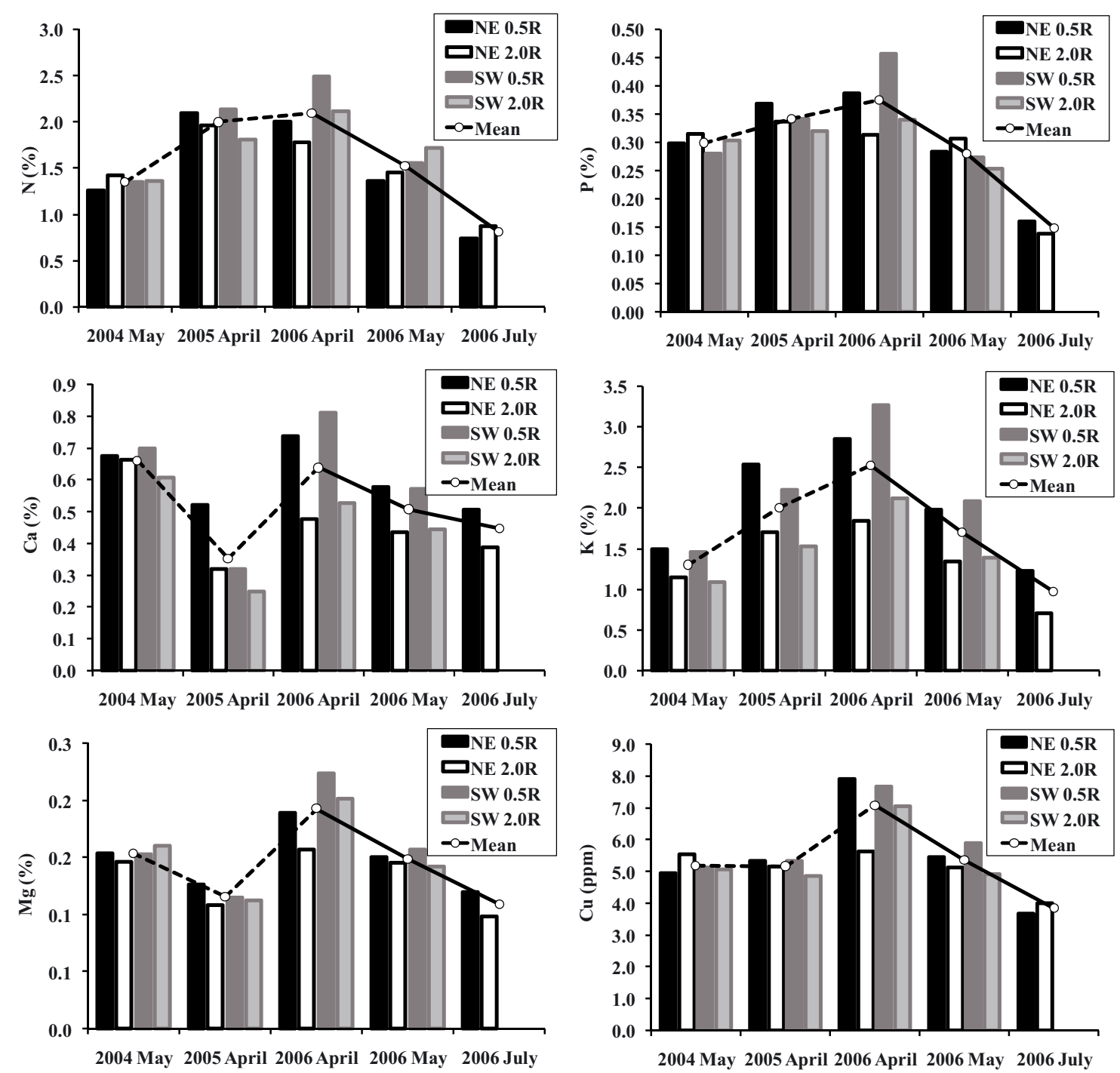

Figure 3. Temporal variation in plant macronutrient and $\mathrm{Cu}$ content. Solid lines depict the mean annual decline over the growing season in 2006. Dashed line serve as a reference for mean values in 2004 and 2005, where only one sampling was carried out.
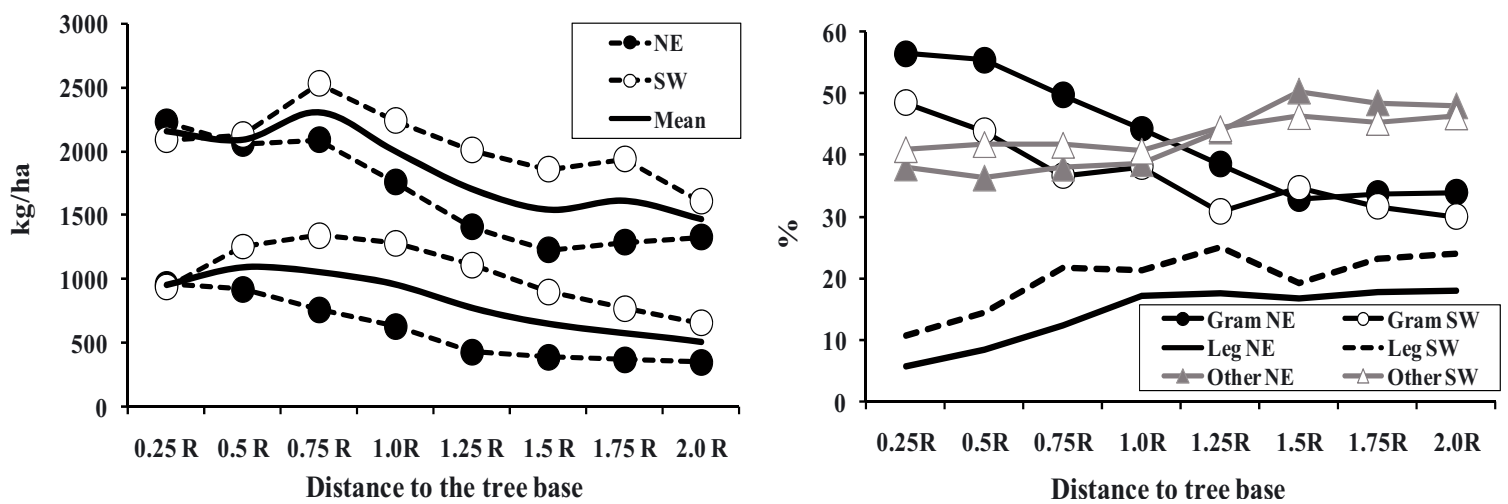

Figure 4. Average (data from 2004-2006) grassland yield (left graph) and composition (right graph) depending on the position with respect to the tree. Data are from Gea-Izquierdo et al. 2009. In the yield figure, upper graphs correspond to May results; whereas lower graphs correspond to April. Grassland composition: Gram $=\%$ graminae; Leg $=\%$ leguminosae; Other $=\%$ other botanical families. 

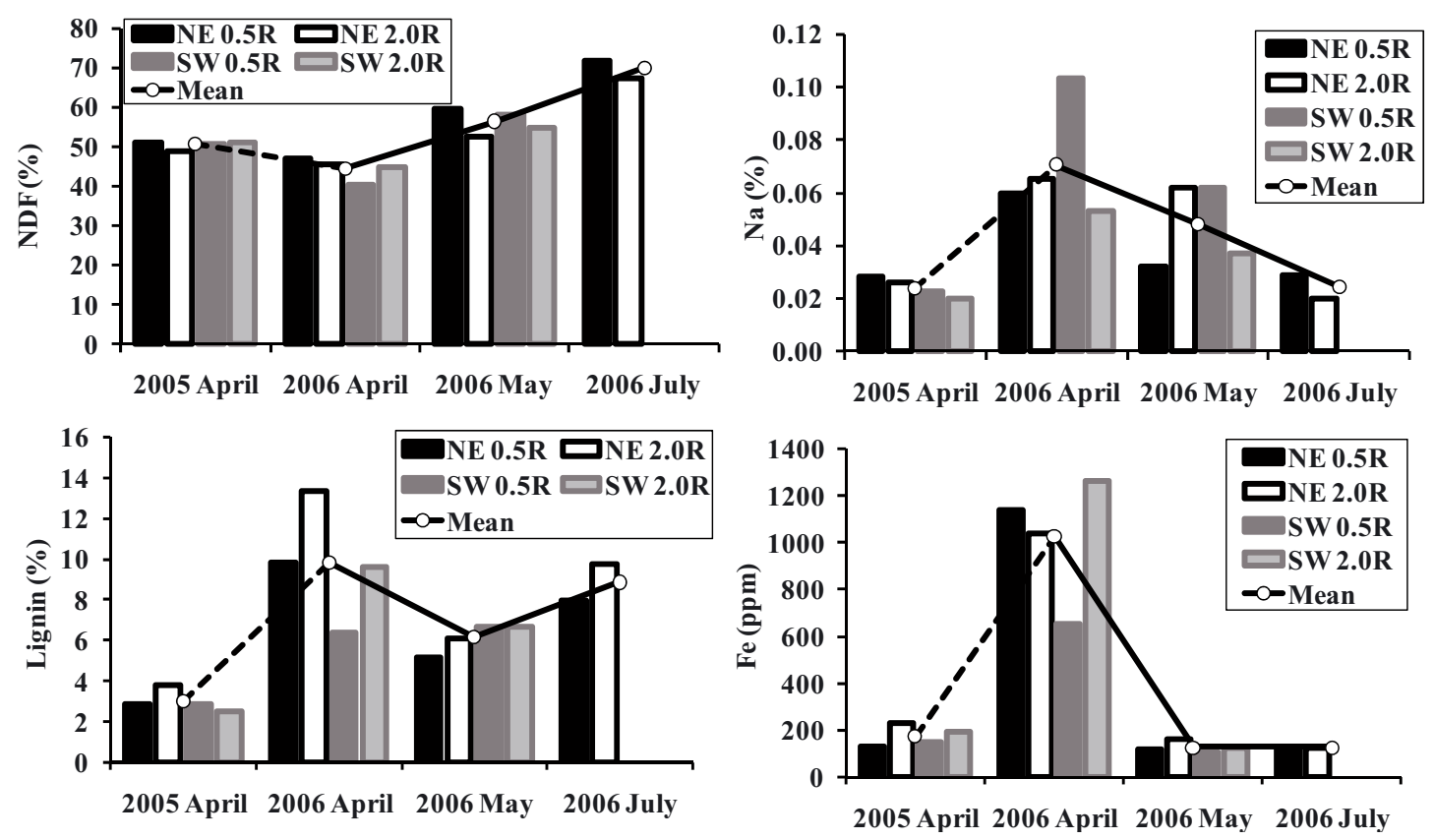

Figure 5. Temporal variation in plant micronutrient and pasture-related variables content. Solid lines depict the mean annual decline over the growing season in 2006. Dashed line serves as a reference for mean values in 2005, when only one sampling was carried out.

no differences were found between distances from the tree. In 2005, the driest year, the amount of lignin was significantly lower $\left(F_{1,28}=54.01, p<0.0001 ;\right.$ Fig. 5$)$.

\section{DISCUSSION}

Most studies analyzing the tree-understory interaction in the studied ecosystem do not consider the small scale spatiotemporal variability. By sampling intensively, the differences in interactions along light interception gradients and the heterogeneity of the responses among different climatic years add valuable information for managing and modelling the ecosystem.

\subsection{Tree effect on the spatial variation of soil nutrients}

The effect of a tree species on soil fertility is likely to vary depending on the type of bedrock, climate and forest management (Augusto et al., 2002). The negative correlation observed between distance from the tree and top-soil $\mathrm{OM}, \mathrm{N}, \mathrm{K}, \mathrm{Ca}, \mathrm{Mg}$ and CEC is a constant in the literature (e.g. Gallardo, 2003; Gallardo et al., 2000; Rhoades, 1997). In the present study, we only analyze the top $20 \mathrm{~cm}$ of the soil, since this is where the roots of annuals are found and where the influence of trees tends to be maximal (Augusto et al., 2002). Trees modify the soil beneath them, although the timescale involved is an aspect which still needs to be addressed (Ludwig et al., 2001). The influence of the tree goes beyond the crown limit and is spatially heterogeneous and asymmetric. In addition, the influence of animals sheltering below the tree canopies may be more important in the redistribution of nutrients than the direct effect of the tree. To our knowledge, this factor has not been quantified in any study to date.

Regardless of the substrate, the chemical composition of holm oak litterfall is particularly rich in $\mathrm{Ca}$ as well as (although in lesser amounts) $\mathrm{N}, \mathrm{K}$ and $\mathrm{Mg}$. The P content is the lowest in comparison to the other macronutrients (e.g. Escudero et al., 1985; Rodá et al., 1999). The lack of clear trends found in soil-P contrasts with the results of most other studies concerning these systems, which report a higher P supply below the canopy (Joffre et al. 1988; Moreno et al., 2007; Puerto and Rico, 1988), although there are exceptions (Montoya, 1982). Dehesa soils have always been considered deficient in $\mathrm{P}$ and $\mathrm{Ca}$, particularly if compared with agronomic soils in the same area. Therefore P fertilization is common (Olea and San Miguel, 2006).

The increase in $\mathrm{pH}$ with proximity to the tree might be expected given the behaviour of other variables studied (mostly $\mathrm{Ca}$, but also CEC and OM). A number of studies (in which the $\mathrm{pH}$ was around 5.5) report an increase in $\mathrm{pH}$ (e.g. Puerto and Rico, 1988; Rhoades, 1997) whereas other studies (in which the $\mathrm{pH}$ was generally higher) do not (Gallardo et al., 2000; Montoya, 1982; Moreno et al., 2007). Plants can both increase or decrease the $\mathrm{pH}$ depending on the composition of the organic matter they produce and the soil $\mathrm{pH}$ and texture (Augusto et al., 2002; Brady and Weil, 2002). Holm oaks might increase the soil-pH only in very acid soils, with the consequent benefits to plants. This occurred in most of the cited studies, but not all (Moreno et al., 2007). The bulk density of the soil was directly related to distance from the tree, as density is indirectly dependent on the abundance of $\mathrm{OM}$ 
and fine particles (Brady and Weil, 2002). In addition to the spatial variation with distance from the tree, the nutrient content was affected by differences in solar radiation induced by different orientations of the canopy. OM and $\mathrm{K}, \mathrm{Mg}, \mathrm{Ca}, \mathrm{N}$ and to a lesser extent, clay, were less abundant in soils on the NE side of the trees in comparison to those (at the same distance from the tree) on the SW side, which received more light. Grass yield was also greater to the SW (Fig. 4). A similar effect on soil texture has been reported in some studies (Puerto and Rico, 1988) but not in others (Moreno et al., 2007), although sampling was less intensive. This systematic slight increase in clay content found in SW locations might be related to the neo-formation or migration of clay to deeper horizons in more humid soils (Schaetzel and Anderson, 2006). Nevertheless, clay exhibited high variability (Fig. 1), and the mentioned differences might just be a consequence of soil heterogeneity.

\subsection{Tree effects on the spatio-temporal variability of plant macro nutrients}

Summer water stress is the main limiting factor in Mediterranean ecosystems, although in the case of annual grasslands, precipitation induced stress in summer is likely to be secondary to nutrient availability in spring. Although the availability of nutrients to plants depends on the presence of moisture, annuals have adapted to drought through ephemeral life cycles linked to the rainy periods, hence avoiding the high water stress associated with the summer. In other studies concerning "dehesas", increases in plant nutrient concentration below the canopy were greater in those soils where the original nutrient content was lowest (Puerto and Rico, 1996). Therefore we expected plants growing in the studied soil to respond to enhanced fertility below trees by a significant increase in nutrient concentration (Barker and Pilbeam, 2007; Ludwig et al., 2001). However, this was not the case except for $\mathrm{K}$ and $\mathrm{Ca}$ (Figs. 2, 3). It is difficult to ascertain which nutrient is limiting, if any, as there are many interactions among nutrients that could hinder growth (e.g. antagonistic relationships between plant uptake of $\mathrm{Mg}^{2+}$ and that of $\mathrm{K}^{+}$and $\mathrm{Ca}^{+}$). A deficiency of certain nutrients may also be triggered by an increase in other nutrients (e.g. $\mathrm{Cu}$ or $\mathrm{P}$ when $\mathrm{N}$ fertilizer is applied, Barker and Pilbeam, 2007). Factors such as plant age, nutrient supply, and botanical composition are directly related to plant nutrient concentration (Barker and Pilbeam, 2007), and these factors can be highly correlated (e.g. botanical composition and soil nutrient availability).

In the ecosystem studied, the phenology and plant botanical composition might be the most important factors determining grass nutrient concentrations both in annual and annualperennial grasslands (Barker and Pilbeam, 2007; Montalvo et al., 1980). However, our results offer little insight into how soil nutrients affect botanical composition and how this is responsible for grass community nutrient concentrations. All the nutrients analyzed exhibited greater temporal variability than spatial, and the most important factor determining plant nutrient concentration was the phenological stage of annual species, which is something known (e.g. Olea et al.,
1990-1991; Pérez Corona et al., 1998). Grasses comprise the functional group which is most abundant below canopy (e.g. Montalvo et al., 1980; Puerto and Rico, 1996; Fig. 4). They are negatively related to plant tissue nutrient concentration $(\mathrm{N}$, $\mathrm{P}, \mathrm{K}, \mathrm{Ca}, \mathrm{Mg}, \mathrm{N}$, and $\mathrm{Fe}$ ), whereas legumes display the highest tissue nutrient levels, including N, P and Ca, (e.g. Barker and Pilbeam, 2007; Pérez Corona et al., 1998; Fig. 4).

Yield increased below canopy (Fig. 4; Gea-Izquierdo, 2009) but this was not accompanied by a higher concentration of most nutrients in plant tissues. Several authors report an increase in plant $\mathrm{N}$ with increased $\mathrm{N}$ supply (Barker and Pilbeam, 2007; Puerto and Rico, 1996), whereas other authors report similar results to those of the present study (Montalvo et al., 1980). Plant-N concentration may reflect higher legume content in less shaded conditions beyond the canopy, rather than to $\mathrm{N}$ supply and/or to interactions with other nutrients. The high variability of legumes and their greater abundance in the late season in the studied grassland (Gea-Izquierdo, 2009) could explain the oscillating differences found in plant- $\mathrm{N}$ between years and sampling dates, a finding which was also reported by Puerto et al. (1984). The N:P ratio has been suggested as a tool to test whether plants are limited by $\mathrm{N}$ or P (Koerselman and Meuleman, 1996; Ludwig et al., 2001). This ratio $($ mean $=5.6, \mathrm{SD}=1.7$; no difference between below/beyond) would indicate $\mathrm{N}$ limitation, rather than $\mathrm{P}$ limitation, but differences between grassland type could invalidate this hypothesis. The $\mathrm{N}$ limitation hypothesis is also supported by the fact that luxury consumption of $\mathrm{N}$ is likely if it is not limiting (Koerselman and Meuleman, 1996). The plant-P levels identified in this study are considered sufficient for most crops, whereas plant-N levels would be considered low for some plant species (Barker and Pilbeam, 2007). Greater nutrient availability in soils might imply a change in grassland species composition rather than a change in plant nutrients.

Plant-P did not show a clear trend with distance or orientation, which agrees with the findings of Pérez Corona et al. (1998) but conflicts with most other studies on the system (Montalvo et al., 1980; Puerto and Rico, 1984, 1996). Plant-K was the only nutrient that clearly increased below canopy in the findings of all studies regardless of the grassland type (Montalvo et al., 1980; Puerto and Rico, 1984, 1996). This may reflect soil-K availability, probably through luxury consumption (Barker and Pilbeam, 2007; Brady and Weil, 2002). Plant-Ca levels were only higher in the positions closest to the tree, although this finding is not shared by all previous studies (Montalvo et al., 1980) and is probably a reflection of $\mathrm{pH}$ or plant composition (Puerto and Rico, 1996). Ca is likely to be deficient in the studied grassland as a consequence of low soil pH (Fig. 1; Tab. I). There was no increase in plant-Mg below canopy. This nutrient only appears to respond to canopy fertilization in certain situations and particular sampling dates, in a similar way to plant-N (Montalvo et al., 1980; Puerto and Rico, 1984, 1996). Radiation did not significantly change the majority of plant nutrients, although low precipitation levels such as those of 2005 may explain the greater reduction in $\mathrm{Ca}$ and $\mathrm{Mg}$ levels, perhaps as a result of lower solubility (Brady and Weil, 2002). 


\subsection{Tree effect on grass variables of pastoral interest}

There was no notable spatial variation for any of the pasture-related variables, and the differences identified might also be explained by phenological differences between orientations (Pérez Corona et al., 1998; Vázquez de Aldana et al., 2001). Again, the decrease in plant tissue nutrients throughout the growing season was the factor which explained the most variability. The quality of the studied pasture is poor, even in comparison to those described in other studies within the same ecosystem, which are also considered of poor quality for livestock (e.g. Olea et al., 1990-1991; Olea and San Miguel, 2006). Lignin content fluctuated and no trend was detected. This result was unexpected since other studies had reported an increase similar to that of NDF and ADF (Pérez Corona et al., 1998). Cell walls are thinner in legumes than in grasses, hence they are more palatable and digestible to animals (Pérez Corona et al., 1995). The decrease found in $\mathrm{Na}$ concentration during grass senescence was not observed in other studies concerning the system (Montalvo et al. 1980; Pérez Corona et al., 1998; Puerto et al., 1984). These studies report greater levels of $\mathrm{Na}$ beyond the canopy whereas we found no difference.

No increase was detected in cell-wall (NDF, ADF, and lignin) in the driest year beneath the tree canopy. Delayed phenology due to the presence of the tree is positive for animal feeding in dehesa ecosystems, since it contributes to reducing seasonal heterogeneity in pasture availability (Montoya, 1982) as pasture growth in these annual communities mainly takes place in April-May (around 70\% of the annual yield, according to Olea et al., 1990-91). Moreover, an increase in nutrient content in late spring and summer (for instance, as a result of an increase in legumes through livestock dung recycling, Olea and San Miguel, 2006) may lead to an increase in the number of animals sustained by the natural vegetation and reduce the need for supplementary feeding.

\section{CONCLUSIONS}

Temporal variability, particularly that related to plant phenological development, is the most influential factor determining plant nutrient content in the annual grassland studied. Soil nutrients around trees are displaced heterogeneously, with greater levels of most macronutrients in locations receiving more radiation. There are many ecological interactions that obscure the relationships discussed. The increase in soil OM, $\mathrm{N}, \mathrm{K}, \mathrm{Mg}, \mathrm{Ca}$ and CEC supply, and enhancement of absorption conditions through increases in $\mathrm{pH}$, was not followed by an increase in plant nutrient concentrations below canopy, with the exception of $\mathrm{K}$ and $\mathrm{Ca}$. Thus, the enhanced fertility permitted an increase in biomass growth that resulted in more accumulated nutrients below canopy, but not in higher plant concentrations. Plant-K has been found to increase below canopies in all studies, with all other nutrients varying, depending on the interaction between soil properties ( $\mathrm{pH}$, soil fertility) and grass composition, which in turn depends largely on soil properties and precipitation. Thus, it would be necessary to carry out field experiments isolating single ecological factors in order to determine specific effects that are impossible to differentiate analyzing natural patterns only.

Acknowledgements: We would like to thank María Peña and the "Instituto Arbitral Agroalimentario" for carrying out the chemical analyses from the 2004 data. Special thanks to the "Dehesón del Encinar" and Celia López-Carrasco for their collaboration in setting up the trial and making the study possible.

\section{REFERENCES}

Augusto L., Ranger J., Binkley D., and Rothe A., 2002. Impact of several common tree species of European temperate forests on soil fertility. Ann. For. Sci. 59: 233-253.

Barker A.V. and Pilbeam D.J., 2007. Handbook of plant nutrition, CRC, Taylor \& Francis

Brady N.C. and Weil, R.R., 2002, The nature and properties of soils, 13th edition, Prentice Hall, NJ.

Brooker R.W., Maestre F.T., Callaway R.M., Lortie C.L., Cavieres L., Kunstler G., et al., 2008. Facilitation in plant communities: the past, the present, and the future. J. Ecol. 96: 18-34.

De Schrijver A., Geudens G., Augusto L., Staelens J., Mertens J., Wuyts K., Gielis L., and Verheyen K., 2007. The effect of forest type on throughfall deposition and seepage flux: a review. Oecologia 153: 663-674.

Escudero A., García B., Gómez J.M., and Luis E., 1985. The nutrient cyling in Quercus rotundifolia and Quercus pyrenaica ecosystems ("dehesas") of Spain. Acta Oecol. Oecol. Plant. 6: 73-86.

Eviner V.T. and Chapin III F.S., 2003. Functional matrix: a conceptual framework for predicting multiple plant effects on ecosystem processes. Ann. Rev. Ecol. S. 34: 455-485.

Gallardo A., Rodríguez J.J., Covelo F., and Fernández Alés R., 2000. Soil nitrogen in a Dehesa ecosystem. Plant Soil 222: 71-82.

Gallardo A., 2003. Effect of tree canopy on the spatial distribution of soil nutrients in a Mediterranean Dehesa. Pedobiologia 47: 117-125.

Gea-Izquierdo G., Montero G., and Cañellas I., 2009. Changes in limiting resources determine spatio-temporal variability in tree-grass interactions. Agrofor. Syst. 76: 375-387.

Joffre R., Vacher J., De los Llanos C., and Long G., 1988. The dehesa: an agrosilvopastoral system of the Mediterranean region with special reference to the Sierra Morena area of Spain. Agrofor. Syst. 6: 71-96.

Koerselman W. and Meuleman A.F.M., 1996. The vegetation N:P ratio: a new tool to detect the nature of nutrient limitation. J. Appl. Ecol. 33: 1441-1450.

Ludwig F., de Kroon H., Prins H.H.T., and Berendse F., 2001. Effects of nutrients and shade on tree-grass interactions in East-African savannas. J. Veg. Sci. 12: 579-588.

Ludwig F., de Kroon H., Berendse F., and Prins H.H.T., 2004. The influence of savanna trees on nutrient, water and light availability and the understorey vegetation. Plant Ecol. 170: 93-105.

Montalvo M.I., García B., Luis E., and Gómez J.M., 1980. Influencia del arbolado sobre la composición química de la hierba. Anales de Edafología y Agrobiología 39: 1287-1305.

Montoya J.M., 1982. Efectos del arbolado de las dehesas sobre los factores ecológicos que actúan al nivel del sotobosque. Anales INIA/Serie Forestal 5: 61-85.

Moreno G., Obrador J.J., and García A., 2007. Impact of evergreen oaks on soil fertility and crop production in intercropped dehesas. Agric. Ecosyst. Environ. 119: 270-280.

Olea L., Paredes J., and Verdasco M.P., 1990-1991. Características y producción de los pastos de las dehesas del S.O. de la Península Ibérica. Pastos 20-21: 131-156.

Olea L. and San Miguel A., 2006. The Spanish dehesas: A traditional Mediterranean silvopastoral system linking production and nature conservation. Grassland Science in Europe 11: 3-13. 
Pérez Corona M.E., García A., García B., and Vázquez de Aldana B.R., 1995. Patterns of aboveground herbage production and nutritional quality structure on semiarid grasslands. Commun. Soil Sci. Plant. Anal. 26: 1323-1341.

Pérez Corona M.E., Vázquez de Aldana B.R., García B., and García A., 1998. Variation in nutritional quality and biomass production of semiarid grasslands. J. Range Manage. 51: 570-576.

Puerto A., Rico M., Gómez G.J.M., García J.A., and Rodríguez R., 1984. Influencia de la encina sobre la composición química del estrato herbáceo. Stud. Oecol. V: 151-168.

Puerto A. and Rico M., 1988. Influence of tree canopy (Quercus rotundifolia Lam. and Quercus pyrenaica Willd.) on old field succession in marginal areas of Central-Western Spain. Acta Oecol. 9: 337-358.

Puerto A. and Rico M., 1992. Spatial variability on slopes of Mediterranean grasslands: structural discontinuities in strongly contrasting topographic gradients. Vegetatio 98: 23-31.
Puerto A. and Rico M., 1996. Trees as a homogenizing factor of the herbaceous community structure and nutrient content in Mediterranean grasslands. Agrochimica XL: 197-208.

Rhoades C.C., 1997. Single-tree influences on soil properties in agroforestry: lessons from natural forest and savanna ecosystems. Agrofor. Syst. 35: 71-94.

Rodá R., Retana J., Gracia C.A., and Bellot J. 1999. Ecology of Mediterranean evergreen oak forests, Springer-Verlag, Berlin, $373 \mathrm{p}$.

Schaetzel R.J. and Anderson S., 2006. Soil: genesis and geomorphology, Cambridge University Press.

Vázquez de Aldana B.R., García A., Pérez M.E., and García B., 2000. Nutritional quality of semi-arid grassland in western Spain over a 10 year period: changes in chemical composition of grasses, legumes and forbs. Grass Forage Sci. 55: 209-220.

Verbeke G. and Molenberghs G., 2000. Linear mixed models for longitudinal data, Springer-Verlag, New York. 